time and otherwise would continue to he wasted, so far as prevention and a repetition of the accident are concerned.

3. Safety measures that are automatic in their function and operation, both obtained at a minimum of cost.

4. Relief of courts of law from the burden of time and expense in passing on the party at fault-the manufacturer as an employer, or the employee through negligence.

5. Universality and automatism of action and scope, whether the machine is a clattering loom in a New England cotton factory, a fast perfecting printing-press in New York City, or a threshing-machine on some Western farm.

(j. Ingenuity of the mechanician or draftsman brought into play at the erection or construction of the machine, in order that the buikler or agent may receive low rates on his bond or insurance for a well-protected machine, as is the case of a house well protected from fire-resulting in a low rate of insurance.

7. The minimum expense involved at the time of the construction of machinery in covering all dangerous points.

To the manufacturer or employer it should insure:

1. Relief from mental anguish, responsibility and worry after an accident.

2. Avoidance of expense and reduced profits on his output as the sequel to an injury.

3. Tranquillity of mind, in that defects or dangerous parts of machines that may and do cost him treasure will receive attention hereafter, as well as increased quantity and quality of output-minus damages-that he has apparently heretofore lost siglit of.

4. Very little, if any, increase in the cost of machines to him, owing to growing competition and the low cost to the builder of safeguarding machine when it is under construction.

5. The right to sue builder of machine at any time to recover the sum paid for the mechanism, the luw holding the sale or transaction void unless bond has been properly filed in the first instance.

To the employce or mechanic it would insure against:

1. Ihysical pain and misery.

2. Reduced earning capacity.

3. Death, or invalidism for life.

4. The receipt of possible injuries to limbs for which mere money could not hope to offer adequate compensation.

\section{EXTENSIVE WOUND OF THE EYE BY AN INFECTED INSTRUMENT}

\section{RECOVERY WITFI RE'TENTION OF VISLON}

EDWARD ARMITAGE, M.D., M.R.C.S. (Eng.)

Government Physiclan for the District of West Kau, County of Inwall

NAALEHU, T. H.

History.-Between 3 and 4 p. m., May 16, 1910 while Iopa Kahula, an 8-year-old Hawaiian boy, was engaged in cutting an old leather whip-lash with his knife, the lash being suddenly divided, the blade of the knife penetrated his right eye. His mother, on seeing blood and water flowing from the wound, carried him into the house, laid him on a couch, and bound up the eye with a handkerchief. Between 5 and $6 \mathrm{p} . \mathrm{m}$. the same day, I was summoned to see the boy.

Examination.-I found that there was an extensive, incised wound of the sclerotic and cornea, and felt convinced that the eye would eventually be lost. However, I determined to make an endeavor to save it and adopted the following plan of trentment.

Ireatmont.-There being no apparent prolapse of the iris, the eye was thoroughly irrigated with a solution of mercuric chlorid, 1 to 1,000 ; a solution of atropin, containing $1 / 50$ grain was instilled; the eye was covered with a thich layer of cotton-wool and bandaged; the strictest repose in the recumbent position and the most complete quiet were enjoined.
Naalelu is specially renownel for two elimatic features, viz., prevalence of high winds and accumulation of dust; the boy's house was close to the dusty highroad, and was certainly not much cleaner than that of the average poor Hawaiian. Throughout my district of West liau, there was no hospital or semblance of hospital accommodation; and for this reason I decided to examine and dress the eye but once a day, while I most forcibly enjoined on the parents and on the loy limself, that on no account was the dressing to be touched; that the boy was to lie on his back constantly; that soft food only was to be given to him, in order to prevent, ns far as possible, the movement of the facial muscles during matication, and that he was to be brought, still in the recumbent position, lying on a wagon, every morning to my oflice, which was situated not far from his residence.

Every morning the boy was brought to my house, the wound and eye were carefully irrigated with a 1 to 1,000 solution of mercury bichlorid, four drops of a 1 per cent. solution of atropin sulphate were instilled into the right eye, and one drop of the same solution into left eye; then, both eyes were carefully padded over with cotton-wool and carefully bandaged. After the first day or two, 10 grains of sodium salicylate were administered every two hours, throughout the progress of the case.

Entering the selerotic, $1 \mathrm{~mm}$. below the center of the lower border of the cornea, in the "dangerous zone" of Nettleship, the blade of the knife divided the sclerotic and cornea, emerging from the latter $1 \mathrm{~mm}$. below the upper and inner border of the cornea, thus making a somewhat curved incision, which was distant $1 \mathrm{~mm}$. from the inner border of the cornea, the length of the wound being $6 \mathrm{~mm}$.

May 17 there was keratitis and iritis; no pain, but some swelling of the eyelids; the wound appeared to have closed

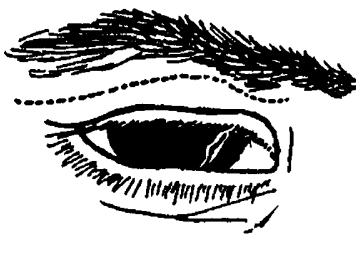

FIg. 1.

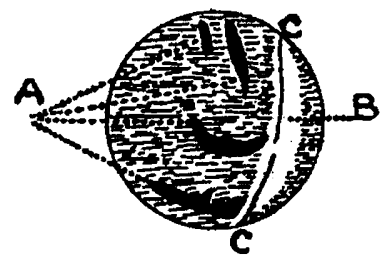

Fig. 2.
Fig. 1.-Ege of patient, after sketch made July 11, showing scar and leukoma; dotted line, veln on lld.

I'lg. 2.-Diagram of the cornea (Sept. 23, 1910); bluck spots (A) indicate apertures in stretched $11 \cdot s$; white stieuk $(B)$, scar und leukoma; line $(C)$, blood-vessels supplying cicatidial tissue.

satisfactorily. May 20 the boy could not see light with the right eye, evidently owing to the previous effusion of blood, and I noticed after the first day or two that the pupil had taken on a grayish tinge, indicating the presence of cyclitis. The above symptoms gradually sulsided, and on May 20 the boy was able to see me with the wounded eye for the first time since the injury. There was no pain on slight pressure on either eyeball, while the corneal wound was completely healed with a leukoma along its borders. May 30 I discontinued the use of the 1 to 1,000 solution of mercuric chlorid and commenced to irrigate the eye with a sterilized solution of boracic acid. May $31 \mathrm{I}$ instilled three drops of a 1 per cent. solution of atropin into the right eye and continued the one drop in the left eye. On June 6 the left eye was exposed, but the one drop of 1 per cent. solution of atropin was still continued every morning. No unpleasant efiects lave followed from the prolonged use of the atropin, and it was only on inquiry on June 9 that I elicited from him the statement that his mouth was dry. June 12 the boracic acill lotion was changed for sterilized physiologic saline solution, and two drops of a l per cent. solution of atropin were instilled into the right eye, the drop in the left eye being continued. The sodium salicylate, 10 grains every two hours, was continued as before. June 13 I supplied the patient with a pair of orange-colored spectacles, in order to ent off the influence of the actinic rays of the spectrum. The bandage was discontinued, but a piece of cotton-wool was placed over the right 
eye, behind the spectncle glass. He was now allowed to sit 11p. June 19 one drop of solution of atropin was instilled into each eye, and June 24 the instillation of the solution of atropin into the left eye was discontinued. June 27 the use of the 1 per cent. solution of atropin was diseontinued in the right eye. July $4 \mathrm{~J}$ made a measurement of the cicatrix and of the leukoma with the eurved strabismometer, and July 11 made a sketch of the eye (Fig. 1).

The cicatrix of the incision presents a beautiful linenr scar bordered by two blood-vessels, and by the leukoma which at its widest part was then $2 \mathrm{~mm}$. in diameter; the length of the corneal cicatrix was $5 \mathrm{~mm}$. August 25 , the boy not having come to see me previously during this month, l made an ophthalmoscopic examination of his right eye.

No delails of the fundus were to be made out by either direct or indirect examination, but oblique focal illumination showed that, since the discontinuation of the atropin, the iris lad been drawn in on all sides toward the cicatrix, completely covering the pupil, but presenting within its texture several apertures through which good vision was obtained (Fig. 2). There was no pain or inconvenience whatever, and no tendency to staphyloma.

September 22 the leukoma mensured $1 \mathrm{~mm}$. at its widest part. The eye, apart from the anterior synechia and the scar, is normal in appearance. Distant vision with the right eye is apparently perfect; the near vision is somewhat difficult to determine, as the patient is unacquainted with the alplabet, but he takes plensure in looking at, and recognizes the objects in picture-books, though when interrogated he says that he sees "sniall" with his right eye.

A peculiar feature in connection with this case is the development of a vein, proceeding from the inner border of the upper eyelid, along the median portion of the lid towards the outer canthus. Possibly this communicated with the angular vein and so with the ophthalmic vein.

Taking into consideration the very successful results which have followed the treatment of the above case and the good vision which the patient possesses with his right eye, I do not propose to perform any operation on the iris at present. At present I nm instilling three drops of a 1 per cent. solution of atropin into the eye daily.

There is an old and time-honored maxim which asserts that "meddlesome midwifery is bad." How much worse is unnecessary interference in the healing process of such a delicate organ as is the eye!

\section{CERERROSPINAL FLUID OF ANOMALOUS CHARACIER IN A CASE OF INTRA- SPINAL TUMOR}

\section{M. COOPER, M.B., Сн.B. SAN FRANCISCO}

Since the cerebrospinal fluid is frequently examined as an aid to the dingnosis of cerebrospinal disease it seems wise that any anomalous finding should be reported.

The fluid withdrawn under a pressure of $100 \mathrm{~mm}$, of water, from a patient without fever, and with signs of a localized segmental lesion of the cord, had the following characters:

Macroscopically, it was clear and of a yellowish-brown color, looking like the clear serous fluid that is aspirated from pleural or peritoneal eflusions. On standing a well-marked cobweb congulum formed. The Noguchi and Nonne globulin tests were strongly positive, thick precipitates occurring. 'The Wassernann complement reaction was negative in the fluid as in the blood.

Microscopically, practically no cells were to be found either in the centrifugalized fluid or in the congulum. No bacteria could be cletected.

Dr. Hyman, who later opernted on the patient, and I came to the conclusion that we were dealing with a case of chronic compression of the cord, probably due to an intraspiual tumor, but an explanntion of the findings in the cerebrospinal fluid did not suggest itself. At operation in strongly marked edema of the membranes was found below the site of the tumor (an angiosarcoma). The transudate character of the fluid seems thus explained.

A similar finding, then, would suggest the presence of a compressing agent plus the probable concomitant occurrence of edema of the membranes, and would warn one to beware of the false localizing signs that may occur with such edemas.

\section{SAPHENOUS VARIX SIMULATING FEMORAL HERNIA}

ALFRED H. NOEHREN, M.D. BUFFALO, N. Y.

'To the well-known saying, "The man who never makes mistakes in diagnosis never does autopsies," I would add "and never operates." Of all the surprises I have ever had, either in operations of my own or in those at which I assisted, the case I am about to describe was the greatest. The rarity of the condition found and the importance of differentiating it from femoral hernia are my reasons for publishing this case.

History.-On Oct. 11,1010 , I was called to see Mrs. K., a woman of 37 , mother of seven children, the youngest being 3 years old, who had always been in good health and had worked hard all her life. She complained of crampy pains all over her

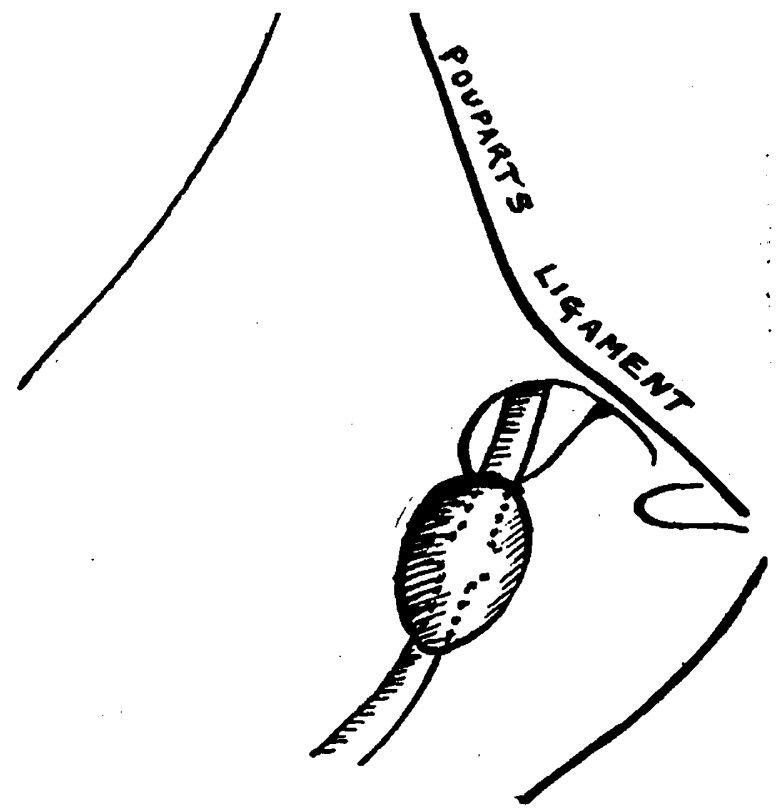

Dlagram of saphenous varix simulating femoral hernia.

abdomen, but most severe on the lower left side, together with continual rumbling of gas. As she had been constipated for a few days, she had taken several doses of castor oil. These increased the pain, although they brought on a fairly good bowel movement. There were no other complaints.

Exanination.-Temperature was 08 F.; pulse, 112 . The abiomen was not tender, was soft, there were no masses felt or swelling noticed. Just below the suphenous opening on the left side, however, was a swelling about as large as a walnut. It was not tender, was easily reducible, especially when the patient lay down, and gave a most decided impulse on coughing. The patient said she had noticed this swelling ever since the birth of her last child and that it had never given her any trouble. I made a diagnosis of femoral hernia and told the patient it would be well to have it operated on, telling her of the danger of strungulation, etc. Her abdominal cramps I attributed to the cathartic and treated her accordingly. 